ARTICLE HISTORY: Received: December 20, 2021 Accepted: February 12, 2022 Published: February 19, 2022

\title{
PERCEPTION AND DISCOURSE OF RUSSIAN ORTHODOX CHURCH IN KOREA
}

\author{
Sevriugin A. Sergei \\ Master of Arts, Graduate Student \\ Graduate School of International Relations, \\ International University of Japan
}

\begin{abstract}
This paper aims to investigate using CDA as the main research tool the image and discourse of Russian Orthodox Church and its missionaries on the Korean peninsula by the turn of the 19th and 20th centuries, as well as their interpretation of such concepts as "religion", "faith" and "believer". Since Orthodox Church commenced its activities there almost simultaneously with Western Christianity, transformed by the Reformation, but attracted only a relatively small number of followers and had a somewhat "non-modern" understanding of the above concepts, it provides a representative case for studying the relationship between religion and modernity. In fact, Russian missionaries could not withstand competition from Protestants, who had remarkably fast subjugated discourse and common sense of religion in the region, and eventually gained the image of "old religion." The author argues that one of the key reasons was its incompatibility with modernity from the perspective of many Koreans. Furthermore, in contrast to Protestantism, which at that point earned the status of truly rational and "ideal" religion, Russian Orthodox Church, full of complex rituals and traditions, could not become the so-called "problematic Other" and thus was assumed as archaic and unhelpful relic of antiquity.
\end{abstract}

Key Words: Russian Orthodox Church (ROC), Problematic Other, Modernity, Religion, Protestantism

\section{List of abbreviations}

CDA - Critical Discourse Analysis

ROC - Russian Orthodox Church

Although most religious people in the Korean Peninsula identify themselves Christians, in this context, such a definition is predominately synonymous with Protestants and, to a lesser extent, Catholics. Arguably, the third largest branch of Christianity in the world, namely the Orthodoxy, has an exceptionally insignificant influence in this territory, despite the fact that it began to spread there roughly at the same intricate period of all-pervading modernization. "Despotic remnant of the past." This is how Orthodoxy was called by the "Tongnip Sinmun (독립신문)," one of the mouthpieces of the Korean independence movement, in the article dated April 1, 1920, dedicated to the expansion of the Protestant church of the "motherland (모국)" in the Russian Far East [12, p.106]. The primary premise for this state of affairs might be its perception among Koreans not as a modern religion and "problematic Other", but rather as something pre-modern and recognizable, which became a consequence of the discourse and activities of Russian missionaries, which specific traits could be vividly exposed through CDA.

In compliance with Jonathan Z. Smith, the Other is not autonomous and always added to yourself as some kind of supplement or even parasite. Like the latter, it is not just somewhere over there, but invades your intimate space. That is why the Other is doomed to become an object of intense theoretical interest. Thus, it appears then the existing paradigm in Thomas Kuhn's terminology and worldview in Ninian Smart's sense are challenged. Only when the simply different poses a problem and turns into alien, the Other is born. Besides, once this problematic Other is recognized, it can no longer be ignored or silenced. The answer must be given. The reaction may be the craving to be like or persistent rejection, but not indifference. [4, pp.275-276].

Otherness itself is more related to the hierarchical structure of status and prestige than to the comparison issue between entities judged equal [4, p.258]. The Other is invariably either higher or lower than you are. By the end of the 19th century, Koreans ranked the West and principally USA and Protestantism, which seemed to be its epitome, as superior. Such an view was form through continuous demonstrations of dominance and imposing a modern religious discourse as something fundamentally better or even "ideal [8, p.31]", while the Orthodox Church initially showed an inclination not to oppose the existing paradigm, but to fit in and conform to it, sharing the pre-modern or rather "nonmodern" [2, p.47] interpretation of religion. ${ }^{1}$

The first chronicled in Chosŏn's sources contact between Koreans and ROC apparently took place in Beijing on October 20, 1735, where its missionary group of four priests and six their disciples resided under the Treaty of Kyakhta 1727. Korean envoy described them thusly: “They big and ugly, and their clothes are similar to Qing people (清國人).

${ }^{1}$ It is worth noting that the author is in no way intend to present Orthodoxy, Protestantism or Catholicism as purer, more correct and original Christianity in this work. As Graham Harvey rightly noted, there is no discrete or primordial form of any religion, and its futile search is beyond the framework of Religious Studies [1, p.38]. 
They said their country is larger than Chinese land and has a system of sŏngji (城池) and kunshin (君臣).” Based on the last remark, the envoy decided that these "big-nosed Talcha" (大鼻㺚子) ${ }^{2}$ were enough "civilized" to have a conversation with the one of them, though there was no mention of Christianity or religion in his notes about this meeting. According to him, the missionaries were mainly keen on issues of an economic and political nature [14, p.24].

In addition, the Chosŏn's representative found their lifestyle so unusual compared to other Europeans that he even doubted their involvement with the Western learning or sŏhak (西學). By this time, the Chinese government and the public accused some members of the Russian Orthodox mission of the incidents of excessive drinking and violence [14, p.23-24]. Apart from that, the third Head of the Russian Orthodox Mission in Beijing Illarion Trussov "repeatedly ridiculed his subordinates and, as a shameless priest, enjoyed wearing Chinese women's clothes. Sometimes he entered the temple (聖堂) in these unsavory garments, not allowing prayer ceremonies to be held properly. Therefore, the Chinese condemned the ROC as a den of crimes." Hence, it was natural for the Chosorn's representative to conclude that the intellectual level of Russian Orthodox missionaries was lower than that of Jesuit missionaries, who were in Beijing at that moment, and they are not of particular interest for a closer study [14, p.26].

Perhaps, because of such a disrepute, the next recorded encounter took place only on April 13, 1828, and Chosŏn envoy's reflection on it was quite ambiguous. "Since all of them spent a lot of time in a foreign land, they seemed lonely and depressed. I could not find any indecent spirit (氣像). Only their habits were weird (怪常). Could not they have completely changed (一新) these un-good customs through Chinese edification (敎化)? Their theories (學說) were so odd (怪異) that I could not even get close to comprehend (接近) them. Besides, their temple of Ch'ŏnju (天主堂) was so bizarre (駭怪) that I closed my eyes and could see nothing. On the day I return home, I should definitely plea people who are going to Beijing not to visit the Russian residence (俄羅斯舘). There is also a Western Pavilion (西洋館) and temple of Ch'ŏnju under the east side of Xuanwu Gate (宣武門), and it is said that from the outside, these grandiose and peculiar buildings are more dominant and spectacular than Yuhe Pavilion (玉河館) ${ }^{3}$. After Shinyusaok (辛西邪獄) ${ }^{4}$ in Korea, no one goes inside them [14, p.30-31]."

It is worth remarking here that for Chosŏn's envoy, Orthodoxy turns out to be an outlandish and obscured to grasp, but obviously inferior to the Chinese thought. It seemed just another strange mystical teaching from foreign land akin to Buddhism, the likes of which had long been exposed and refuted by Neo-Confucian scholars like him. In other words, ROC was not viewed as a clear "problematic Other", as Smith outlined it, and could be easily neglected. At the same time, the envoy still cannot shake off the fear that it may be part of indisputably dangerous and threatening Western learning. The reason for this, as Park Taegeun points out, could also have been the content of books received during this meeting [14, p.31].

Nevertheless, the visit of Chosŏn's envoy to the mission of ROC on October 25 of the same year may indicate that Orthodoxy was not ultimately taken as part of the Western learning. "Russian residence (俄羅斯舘) is located next to the Yuhe Bridge (玉河橋). There is a high pavilion behind two inner gates. I was very surprised to see a drawing of a disheveled and naked young man bleeding and practically dying with his eyes closed. When I asked who this god (神) they revere (崇尚), I was told that this is a Russian prince (俄羅斯太子) murdered by the Chinese. There was a godspirit (神靈), so they depicted him like that to commemorate his dying image. However, I was also told that this is the image of killed Matteo Ricci (利瑪竇). What words should I believe [14, pp.31-32]?” It seems the author was quite aware of Western learning and Matteo Ricci, but could not correlate them with what he knows about Orthodoxy and saw in the Russian residence. In particular, the painting he discovered rather reminded him of the images of gods, revered ancestors and rulers understandable to Korean than a symbol of Western learning. Therefore, this time, Chosonn's envoy considers it unnecessary to close eyes and experience surprise instead of fear.

A similar outlook at Orthodoxy as something has long been known, rather than a "problematic Other," can be found in the records of Russian missionaries about their activities on the Korean peninsula. For example, acolyte Ioana Levchenko noted many Koreans think that the rituals familiar to them in some way resemble the ceremonies of the Orthodox Church. "Having been brought up on Confucian books that instruct the followers to perform all kinds of ceremonies, most Koreans are advocates of external ritual service as an expression of one or another religious idea. All our Orthodox rituals are distinguished by the very precious specificity that clearly articulates Christian truths, which through these rituals are more easily recognized and deeply taken root in the consciousness. That is why Koreans

${ }^{2}$ The term Talcha (㺚子), as well as Taltan (獺靼), was used in Chosŏn's documents to refer to peoples living east of Mongolia.

${ }^{3}$ A place originally assigned for Chosŏn's envoys for residence, but by the beginning of the 18th century transferred to the Russian representatives.

${ }^{4}$ The first massive anti-Catholic purges in Korea in 1801, also known as Sinyu Persecution. 
observe all the actions of the priest during the divine service with such attention, treat sacred images and objects with childish love and respect, place the sign of the cross on themselves with particular care and in general have goodwill (благорасположение) for the entire ritual aspect of our Orthodox worship [5, p.254]."

Here, the preservation of rituals can be seen as a way to counter the rational Western Protestant modernity that demands renunciation of collective ceremonies in favor of internal personal faith along with disenchantment and alienation of the sacred [1, p.175]. The outstanding ritualism of the ROC and non-modern accent on the external symbolism, on the other hand, might make some Koreans feel nostalgia and continuity with an idealized past. One of these manifestations was the Chŏng Kiltang's (貞吉堂) uprising. Born into a family of Korean immigrants in Russia and bringing from there more effective in terms of economics and politics image of Orthodoxy, she under the name Vera declared herself an emissary of the emperor and announced the foundation of an Orthodox Church (希臘呚) in the South Ch'ungch'onng province in the fall of 1900. Soon, having united with former members of the Tonhak movement, Chŏng Kiltang, in addition to installing crosses and distributing religious literature, proclaimed herself the supreme legal authority and engaged in mass "property requisitioning" under the auspices of the fair wealth redistribution [13, p.321322]. However, among vast majority of Korean who sought to break with the past and saw Western modernity as a standard, such a non-modern perception of religion could not find a positive response.

Against this background, it is not astonishing that Orthodox Church in Korea until it was transferred to the jurisdiction of the World Patriarch of Constantinople in the 1950s preferred to use the term omyo (奧妙) instead of the more classic for Catholicism and Protestantism words misa (Missa) or sŏngsa (聖事) to indicate church worship [5, p.256]. This is because the first one was the closest translation of Russian word "tainstvo (таинство)", which is a common name for rituals in the discourse of ROC, originally meant secret and mystical action. Moreover, if the misa is a direct calque from Latin and the sŏngsa highlights modern hyperseparation of the sacred (聖), then the omyo in the context of the Korean language at the turn of the 19th and 20th centuries might primarily evoke associations with the socalled “mysticism (神秘主義)", which has long been known and criticized, in particular, on the example of Buddhist and Shamanic practices by Neo-Confucian scholars in Korea striving to abandon the worship of gods and adopt a "realistic" worldview [11, p.390-391].

The Russian Orthodox Church's tolerant position toward ancestor worship, which both Protestants and Catholics vigorously opposed, reinforced its image of "old" or rather "non-modern religion." Pavel Ivanovsky, the head of the ROC mission in Korea from 1904 to 1912, wrote on this topic thusly: "Protestant missions see the fundamental brake on their enterprises in the worship of ancestors by Koreans. This is understandable because respect for parents and ancestors among Koreans is a cornerstone of social and religious life. Protestants do not acknowledge prayers for the dead. Another thing is the Orthodox Church. Its highly artistic and touching funeral rites, the service of sorokoust ${ }^{5}$, memorial services, special days of the deceased commemoration - common and individual - all this should please Koreans. Now, if we discard the worship of spirits, the unworthy and illegal in the Korean cult of ancestors, then everything else will serve not as a hindrance, but, on the contrary, help the affairs of the Orthodox mission [5, p.260]."

This passage distinctly illustrates that Russian missionaries were extraordinarily sympathetic towards NeoConfucian ideas, spotting in them several features analogous to Orthodoxy. In their recordings virtually no accusations of the Koreans in "fetishism" and "idolatry", which were widespread among Protestants. As bishopp Innokenty of Ussuri pointed out, Orthodox missionaries eventually concluded through experience, "there is no need to suddenly break certain established habits [7, p.304]." Besides, the aforementioned struggle against the worship of spirits and the preservation of the cult of ancestors was likewise one of the chief concerns for Neo-Confucian scholars. Furthermore, the proximity of Orthodoxy to the pre-modern religious discourse of Korea does not end here. For instance, the school at ROC mission in Seoul taught "Thousand Character Classic (千字文)" to students [5, p.260] and its head advised parishioners to pray for the Emperor Kochong [9, p.151]. The latter fact sounds especially out of the ordinary, since the ruler of Korea was not simply far from a legitimate Christian monarch but also regularly accused by Protestants of the decline and lack of modernity in the country [10, p.68].

In this respect, the discourse of Orthodox missionaries can be compared to Nestorian one. This Christian denomination did not provoke to fundamental changes in worldview and any noticeable reaction as a "problematic Other" in East Asia as it happened after the penetration of Catholicism and Protestantism into the region in the 16th and 19th centuries, respectively. Nestorians did not challenge the already established social structure and religious discourse, being quite successfully integrated into them. Since this denomination put more stress on spiritual practice, rituals, and direct contact with the God rather than salvation, it was quickly accepted and assimilated as another mysterious, but not

${ }^{5}$ Sorokoust or forty divine liturgies in the Russian Orthodox Church is a series of commemoration rituals in memory of a dead person, which usually last for 40 days. The number forty comes from the tradition that it takes 40 days for the soul to reach the throne of God. In this regard, parallels can also be drawn here with the Korean Confucian concept of hon (魂) and baek (魄), into which, according to $\mathrm{Zhu} \mathrm{Xi}$, a deceased person is divided. Complete dissolution of which also requires time and repetition of the remembrance rituals. 
dangerous Buddhist sect. Christian monotheistic God was easily translated as "Buddha" (佛), angels as "arhans" (阿羅漢), and the Gospel as “sutra” (經) (3, p.121). They all were merely one of many. In Smith's words, “as long as you succeed in giving your own form to those strange people and their customs, they will not appear as true Other [4, p.270]."

In a similar way, the Orthodox Church associated more with old traditions rather than with something modern, which was perhaps most vividly expressed in these words of the Korean parishioner to Russian missioner, quoted by Yim Young-Sang. "The way our and your countries are governed is the same - monarchy (王政). You love your emperor and pray for him in the church. We love our emperor and pray for him just like you. We like the fact that your attitude toward religion (宗敎) is strict, unlike other missionaries. In addition, we are neighboring country of Russia, so we want to be like you [9, pp.150-151]."

The strict attitude to religion of Orthodox missionaries, about which he speaks, might be characterized in essence by the adamant aspire to "overcome the absurd social motives" of conversion [7, p.297]. Instead, the most important task, apparently, was the formation of what Perevalov, head of the ROC mission in Korea from 1917 to 1927, called "living religious feeling" [6, p.30], which was often set against highly rationalized modern religion of Western Christianity. Therefore, any attempts to regard conversion as a way of dealing with personal, social or political troubles were seen by Orthodox missionaries, in contrast to Protestant ones [8, p.32], extremely negative.

The case of Iosif Han (Иосиф Хан), who "not satisfied with American feed, left his previous employment, becoming an Orthodox catechist, not being an Orthodox himself," could be a representative example of this approach. Perevalov wrote the following about him: "If you accept the Russian faith, the homegrown orator spoke out, then it will be good and profitable for you: you will have clothes, money, and protection in front of your superiors... Russian people are very rich and kind. They love their faith and help those who take it from them... Americans will not give you anything. They themselves look into the pocket of others... They strive how to get from us, not give us." Then Perevalov concludes that such individuals have done a lot of harm to the missionary work in Korea [6, p.60].

However, despite all attempts, the Orthodox missionaries evidently failed to form a "living religious feeling." Testimony of that is made explicit in the final conclusions of the Perevalov about Koreans and work among them. One of his major disappointments was their excessive pragmatism, which may be attributed to requirements of modernity as well as what Harry Garuba and Graham Harvey described as "animist materialism." ${ }^{\prime \prime}$ In other words, religion is accepted and practiced to the extent that there is a definite need for it, whether it is healing with shamanic rituals or the patronage and financial support of missionaries. That is why Korean, in line with Perevalov, might have multiple religions at once or not have any at all, often combining and adding a new one. It is curious that many of them explained such an attitude by the fact that "they did not believe in anything, because no one from the other world came to them, they did not see anyone, did not touch anyone [6, pp.145-146]."

Perevalov argued such a worldview, "if it can be called a worldview," is incompatible with "real" religion, but rather a superstition. "Koreans have no religion in the sense that we understand" and the most of them "was and is outside the faith, living without any confessional (вероисповедального) cult, and at least officially does not appear to belong to any of the religions in the country. Indeed, some Koreans sometimes turn to Confucianism, Buddhism or shamanism (most of all to shamanism) on occasion, but only on occasion! If there is no occasion, then there is no need for that!" As a result, "if a Korean believes in anything, then only himself, that is, he lives with his mind, but not at all with his heart [6, pp.145]."

To encapsulate, on the Korean Peninsula, the Orthodox Church has developed a reputation of "non-modern" religion for several reasons. One of the main ones was the notion of religion on the part of Russian missionaries discourse as something emotional, vernacular and irrational, which did not fit into the modern model of religion brought in by Western and primarily Protestant missionaries as absolutely reasonable, scientifically rational and useful private matter. Coupled with the Orthodox ritualism, its priority of mystical experience and sacralisation of power, this led to the fact that Koreans did not perceive it as the "problematic Other."

\section{References}

1. Harvey Graham. Food, sex and strangers: understanding religion as everyday life. Durham: Acumen, 2013.

2. Latour Bruno. We Have Never Been Modern. Cambridge: Harvard University Press, translated by Catherine Porter, 1993.

3. Liščák Vladimir. Early Chinese Christianity in the Tang Empire: On the Crossroads of Two Cultures. Art, Architecture and Religion Along the Silk Roads. 2009. Vol. 12, pp. 103-125.

4. Smith Z. Jonathan. Relating Religion. Chicago: The University of Chicago Press. 2004.

5. Archimandrite Augustine (Nikitin). Russia and Korea: An Overview of Church Relations. Pravoslavie i Korejcy, edited by Herman and Valentina Kim. Moscow: OOK Publishing Group. 2014. pp. 229-284 (in Russian).

${ }^{6}$ Graham Harvey argued that the so-called animist materialism is inherent in any religion and meant by it a religious philosophy of borrowing, using, and adapting useful elements [1, p.136]. 
6. Archimandrite Feodosij (Perevalov). Russian Spiritual Mission in Korea (1900-1925). Pravoslavie i Korejcy, edited by Herman and Valentina Kim. Moscow: OOK Publishing Group. [1926] 2014. pp. 25-168 (in Russian).

7. Bishop Innokenty of Ussuri (Erohin). Formation and Principles of the Vladivostok Mission. Pravoslavie i Korejcy, edited by Herman and Valentina Kim. Moscow: OOK Publishing Group. 2014. pp. 285-305 (in Russian).

8. Sevriugin A. Sergei, On the History of the Spread of Protestantism on the Korean Peninsula at the End of the 19th - the Beginning of the 20th Centuries. Religiovedenie. Blagoveschensk: Makro-S. 2019. No. 4, pp. 30-36 (in Russian).

9. Yim Young-Sang. The Russian Orthodox Church and Korea. Slavic Research. 1996. Vol. 12, pp. 125-157 (in Korean).

10. Kang Dong-Gu. The Reinterpretation of Protestant Nationalism in the Early Modern Korea. Journal of Religion and Culture. 1999. Vol. 1, pp. 63-79 (in Korean).

11. Kang Dong-Gu. Korean Religious Organizations from the Religious Scholar's Point of View. Seoul: Pangmunsa. 2017 (in Korean).

12. Lee Byong-Jo. An Encounter and Collision of the Russian Orthodox Church and the Protestantism (19091912): in Focus of Missionary Work of Kwanheul Choi and the Presbyterian Church in the Far East and the Countermeasure of the Russian Orthodox Church. Slavic Research. 2008. Vol. 21, No. 1, pp. 97-136 (in Korean).

13. Lee Young-Ho. The Remnants of the Donghak Peasants Army and the Western Religion in the Southwestern Region of Chungcheongnam-do Province. History and Discourse. 2018. Vol. 88, pp. 307-345 (in Korean).

14. Park Taegeun. Russian Expansion to the East and Russian-Korean Negotiations prior to the Establishment of Diplomatic Relations (before 1861). 100-year history of Russian-Korean relations. 1984. pp. 1-49 (in Korean). 